\title{
Milk and Dairies Safety Management. Better understand Consumer Behavior
}

\author{
Marko JELOČNIK ${ }^{1}$ \\ Florentina DRAGNE ${ }^{2}$ \\ Iuliana Denisa RĂDULESCU ${ }^{3}$
}

Abstract

Milk is important in human diet because it contains micronutrients good for health. Milk is one of the basic agricultural products and many researchers have been studied its benefits. This segment of research focuses on milk consumption, as one of the essential food products used in human nutrition. The objective of this paper is to identify the consumers' perceptions about milk quality and safety. Pursuing this, a survey was carried out towards the collection of data about consumer's buying behaviors, their preferences related to milk and dairies, buying frequency and monthly budgets spent in average for these products.

Research findings show that consumers find quality and safety as the most important criteria in choosing milk and dairies, since they have been marked with the highest score among the other criteria, such as price, promotions, or packaging. Gained results are useful for better understanding of consumer's behavior during the purchase of milk and dairy products, as for proper decisions related to further directions within the implementation of food safety management systems in food processing facilities. behavior.

Keywords: milk and dairy products, safety management, quality, survey, consumer

JEL classification: $M 120, M 12, M 52, L 83$

DOI: $10.24818 /$ RMCI.2019.2.144

\section{Introduction}

In its natural form milk possesses a high food value, since it includes a wide variety of nutrients essential for proper growth and maintenance of the human body (Handford et al., 2016). Its importance in human nutrition does not require to be consumed in great quantities in order to take its health benefits. In fact, a glass of milk provides such a high amount of vitamin D as it is contained in $100 \mathrm{gr}$ of salmon, or it carries calcium as it could be found in 200 gr of broccoli. Besides, it contains potassium as a small banana, or vitamin A and phosphorus as it can be found in $200 \mathrm{gr}$ of cooked beans (Stetca et al., 2012).

1 Jeločnik Marko, Institute of Agricultural Economics Belgrade, E-mail: marko_j@jep.bg.ac.rs

2 dragne florentina, The Bucharest University of Economics Studies, E-mail: florentinadragne@yahoo.com

3 Radulescu Iuliana Denisa, The Bucharest University of Economics Studies, E-mail: dennisa_yuliana@yahoo.com 
Milk is a well-accepted and wholesome food, so its nutritional value makes it an ideal and essential food for all age group (Sharma, 2005).

Milk composition mainly varies by the species (cow, goat, or sheep), or type of head within the certain species (e.g. Holstein-Friesian, Jersey, Simmental, etc.), used feed, stage of lactation, etc. Usually in focus is cow milk. The general composition of raw cow's milk contains $87.7 \%$ of water, $4.9 \%$ of lactose (carbohydrates), $3.4 \%$ of fat, $3.3 \%$ of proteins and $0.7 \%$ of minerals (Banu et al., 2007).

Milk proteins have huge biological value, so milk could present excellent source of essential amino acids. Additionally, milk contains a wide range of proteins with different biological activities: from antimicrobial to those who facilitate the nutrients absorption, or who provides a growth factors, or hormones, enzymes, antibodies and immune stimulants (Haug et al., 2007).

Besides, milk is considered as one of the most valuable sources of calcium, phosphorus, potassium, vitamin $\mathrm{D}, \mathrm{A}$ and $\mathrm{B} 12$. According to mentioned aspects, it should not be absent from the diet of young people and adolescents, as it is being simply the elixir of youth and a healthy body (Bratu, 2015).

It should be also noted that in contemporary dairy industry less than $20 \%$ of processed milk is directly availed for produced dairy products, while the rest is transferred into the main by-product - whey that due to insufficient utilization becomes one of the major polluter in processing industry. As it is excellent source of high quality proteins, minerals, vitamins and lactose whey could be used in daily nutrition, or processed into the several valuable food products (Arsić et al, 2018).

Generally, given the diversification of the range of agri-food products, the safety and quality of food products are very common topic. In developed countries, there are established different food production standards, while in less developed countries as the basic problem occur the food safety (usually as critical element).

Thus, the need of studying the concepts of milk and dairy products quality, safety and traceability, the factors that influence them and the quality characteristics of mentioned products, methods for control and estimation of their quality, as the institutional framework on ensuring food safety and security is constantly emerging.

There are three basic factors that affect the food quality, respectively external factors, internal factors and quality standards. They are presented in Figures 1, 2 and 3.

\section{External factors \\ (dimension, form, color, taste, etc.) \\ Factors like Quality Standards}

Internal factors

(chimical, physical,

microbiological, etc.)

Figure 1. Food quality characteristics

Source: Author's contribution according to Ladaru, 2011. 
The food quality is represented by the quality features of food products accepted by consumers. These include external factors, such as appearance, texture, color, aroma, etc., as well internal factors as are physical, chemical, etc., and quality standards (Manole et al., 2003).

Food quality is an important requirement for food production, as consumers are susceptible to any form of contamination that may occur during the food processing. Besides, many consumers rely on production and processing standards, especially in cognition of all ingredients contained within the product, due to dietary requirements, nutritional (e.g. vegetarians) or medical conditions (e.g. related to diabetes or allergies). There are many scientific analysis that have been constantly conducted (by local or national authorities, consumer's associations, food processors and suppliers, etc.) in public in order to monitor the food market according to determination whether the products are in compliance with quality standards or not.

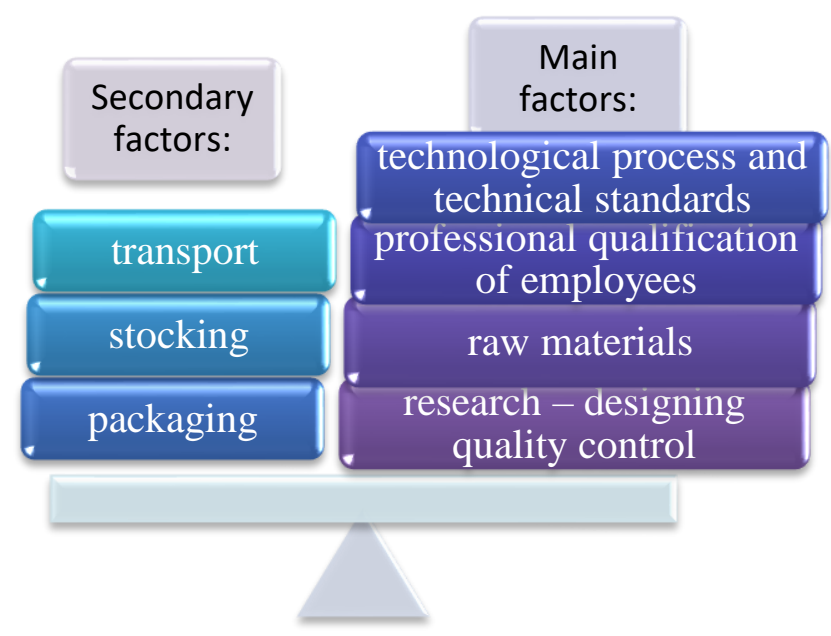

Figure 2. Factors influencing food quality

Source: Author's contribution according to Sandu, 2015.

Nowadays, two major terms related the food availability are food security and safety. First determines that each person at any moment has to have at his disposal a physical, social and economic approach to sufficient and safe volume of food that will satisfy his nutritional needs in line to maintaining of active and healthy life (Jeločnik, Zubović, 2018).

At the other hand, food safety primarily refers to conditions and activities that contribute to the preservation of food quality, as to prevention of its contamination and activation of food-related diseases. It considers the management of a complete food chain (from farm to fork), in terms of food handling, storing and processing (Balambal, 2015).

Food production is particularly vulnerable to long periods of storing. Foodstuff quality is mostly sensitive when products are stored under the conditions of high temperature and humidity. Besides, quality characteristics are deeply leant on 
technical, psycho-sensory, availability, economic, technical, social, and other basic and secondary characteristics of certain food-product (Manole et al., 2003).

Activity closely linked to food security and safety is food products traceability. It involves tracing and identifying of all food, feed, livestock, primary agricultural products, food producing substances and additives used in human consumption, etc., throughout the all stages of food production/processing and distribution. This is a way to respond to the potential food health risks that can arise from food production (ensuring that all foodstuffs are safe for people consumption), (Cao et al., 2011).
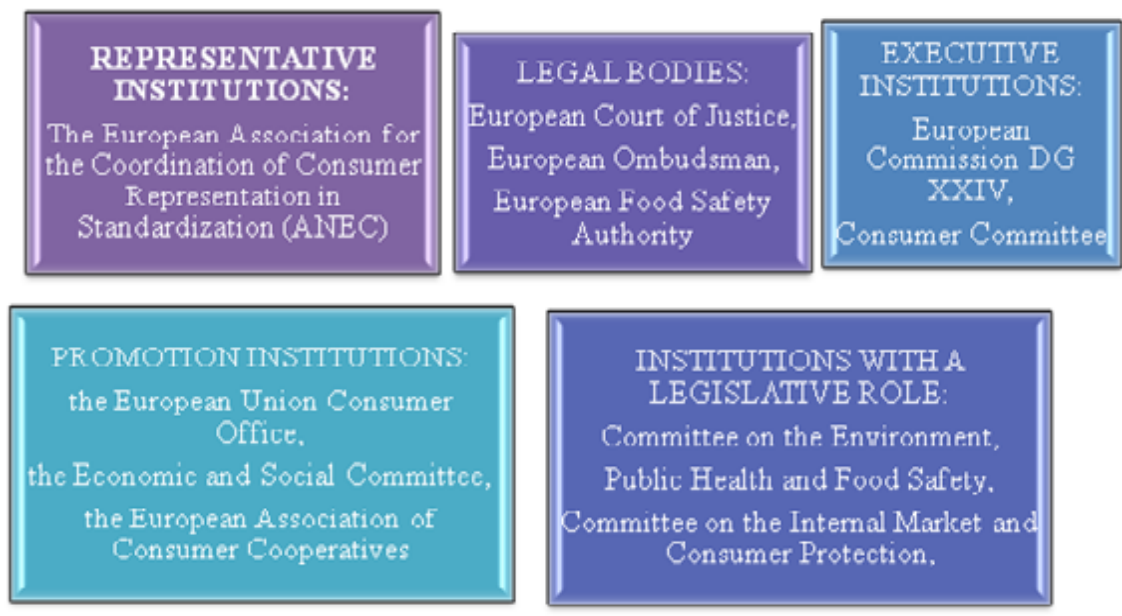

Figure 3. The EU institutional framework for ensuring food safety Source: Author's contribution according to Banu et al., 2007.

The Member States of the EU established several food safety standards, which refer to the content of vitamins, additives, minerals or other substances that come into the contact with the food products. Besides, eleven regulations are set for veterinary control. Certain EU authorities are making decisions what substances could be used in food production (avoiding those supplements that could endanger human health). These standards include veterinary medicines, pesticides, additives and pathogens which enter in the products' composition. National authorities are responsible for prohibiting the use of mentioned substances, by harmonization of national legislation and conduction of periodic controls.

Bearing in mind all the considerations above, the importance of food safety is obvious. Besides, there is a strong need for searching of consumers' perceptions on food safety. In this paper are presented the results obtained from the survey towards the consumers' perception on milk and dairy products safety in Romania. Paper includes few segments, as are background of researched problem, overview of national market of milk and dairy products, description of used methodological approach, defined objectives and hypotheses, discussion of gained results and derived conclusion. 


\section{Current state of milk and dairy products market in Romania}

The dairy market reached 800 million EUR in 2017-2018, ranking the Romania at first place among the developing countries according to increase in milk consumption. The amount of annually collected milk at national level amounts around 5.5 billion liters. Approximately $75 \%$ of the total milk production comes from the northern and central counties (National Institute of Statistics of Romania - INSSE, 2019).

\begin{tabular}{|c|c|c|c|c|c|c|c|c|}
\hline \multicolumn{9}{|l|}{14000} \\
\hline 12000 & & & & & & & & \\
\hline \multicolumn{3}{|l|}{12000} & & & & & & \\
\hline \multicolumn{9}{|l|}{8000} \\
\hline \multicolumn{9}{|l|}{6000} \\
\hline \multicolumn{9}{|l|}{4000} \\
\hline \multicolumn{9}{|l|}{2000} \\
\hline 0 & $\begin{array}{l}\text { Nord- } \\
\text { West }\end{array}$ & Centre & $\begin{array}{c}\text { Nord- } \\
\text { Est }\end{array}$ & Sud-Est & $\begin{array}{l}\text { Sud- } \\
\text { Munten } \\
\text { ia }\end{array}$ & $\begin{array}{c}\text { Buchar } \\
\text { est- } \\
\text { Ilfov }\end{array}$ & $\begin{array}{c}\text { Sud- } \\
\text { West- } \\
\text { Oltenia }\end{array}$ & West \\
\hline 2012 & 8898 & 7756 & 10859 & 5659 & 6754 & 317 & 4791 & 4095 \\
\hline 2013 & 9623 & 7745 & 10905 & 5803 & 6714 & 195 & 4895 & 4194 \\
\hline 2014 & 8990 & 7852 & 10810 & 5751 & 6027 & 200 & 4809 & 3898 \\
\hline 2015 & 8952 & 7889 & 11388 & 5552 & 5921 & 181 & 4845 & 4000 \\
\hline 2016 & 8994 & 8743 & 11807 & 5741 & 5899 & 218 & 5073 & 4060 \\
\hline 2017 & 8899 & 8217 & 11502 & 5655 & 5724 & 222 & 4977 & 3960 \\
\hline 2018 & 8436 & 8194 & 11045 & 5486 & 5837 & 240 & 4857 & 4038 \\
\hline
\end{tabular}

Figure 4. Milk production at regional level (in $000 \mathrm{hl}$ )

Source: author's contribution according to INSSE, 2019

In Figure 4 is presented regional distribution of milk production in Romania for the period 2012-2018. The highest production results are recorded in the North-East, North-West and Center regions, while the lowest production were obtained in BucharestIlfov, West, South-West-Oltenia and South-East regions. The most productive is the North-East region, where the highest value of production (11,807 thousand hectoliters) was recorded in 2014. At the other hand, the Bucharest-Ilfov Region has been achieving the minor milk production (at least in 2015, around 181 thousand hectoliters). 


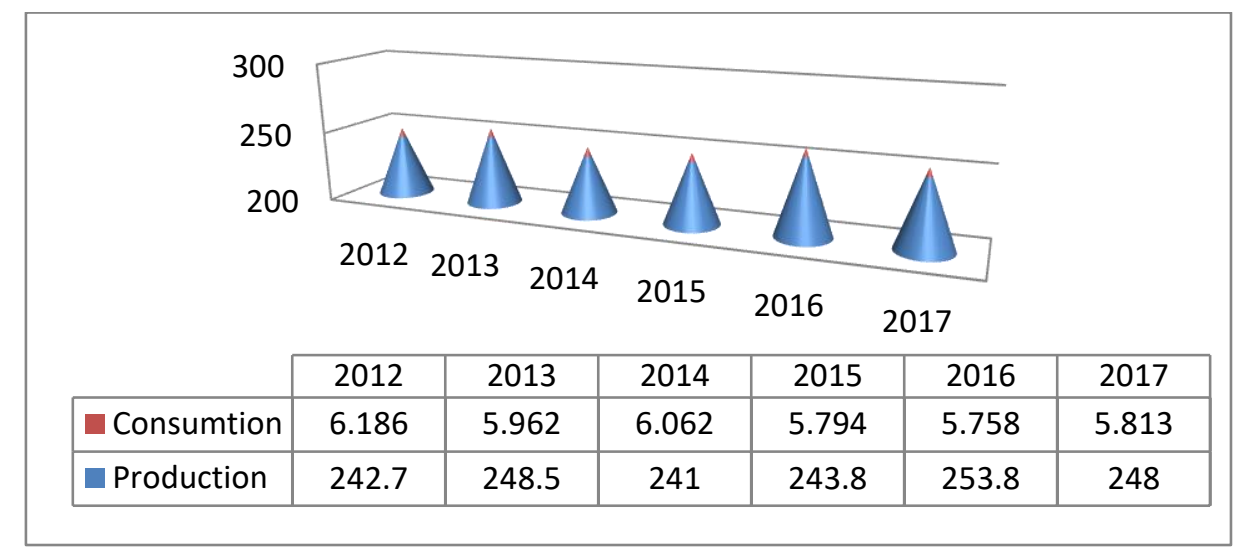

Figure 5. Milk production and consumption per capita per month at national level (in liters)

Source: author's contribution according to INSSE, 2019

At Figure 5 is presented the milk production and consumption at national level per capita per month. It can be seen slight oscillations in produced volume of milk. The highest value (253.8 liters) was recorded in 2014, while the lowest one was achieved in 2012 (241 liters).

The highest milk consumption per capita was recorded in 2012 (6.18 liters per person per month), as well as in 2014 (6.06 liters). Contrary to that, the lowest milk consumption per capita per month was registered in 2015 (5.75 liters). As with production, in general, milk consumption has slight oscillations. For example, since 2013 compared to 2012 it has decreased for $-0,224$ liters (respectively $-3,62 \%$ ). In 2014 compared to 2013, consumption increased by 0.1 liters, or $1.67 \%$. At the end, comparing the 2017 with 2012, there is a decrease of 0.373 liters, i.e. around 6\%.

Besides the general rule that milk consumption per capita is higher in developed than developing countries, it also depends on climate conditions, social impacts and tradition, volume, type and form of milk available at the local market, customer's preferences, etc. In line to country-specifics, more than $150 \mathrm{~kg}$ of milk per capita/year is consumed in Argentina, CIS countries, Costa Rica, Ecuador, most of EU countries, Israel, North America, Oceania, Turkey, Uruguay, Pakistan, etc. Between 30-150 kg of milk per capita/year is consumed in India, Japan, Republic of Korea, North and Southern Africa, most countries of the Middle East and Latin America. Less than $30 \mathrm{~kg}$ per capita/year is used in China, and most countries of Central Africa and East and Southeast Asia (Hemme, Otte, 2010). By previous classification, Romania belongs to second group of countries.

In Table 1 is shown Romanian foreign trade balance for milk and dairy products for the period 2014-2018 (it considers difference between export and import). In whole observed period it achieves negative values (naturally and financially expressed). Shown increase in exports is surprising, in line the fact that over 100 dairy factories have been closed in recent years. Besides, large investors have been invested in local dairy facilities (e.g. the largest investment in last couple years was up to 75 million 
USD in Olympus factory in Brasov. It exports around $75 \%$ of the entire production, representing the largest exporter of dairy products at national level (INTRACEN, 2018).

Tabel 1. Romanian foreign trade balance for milk and dairy products

\begin{tabular}{|c|c|c|c|c|}
\hline Year & npo & ruanti & sBalance (tones) alue (EUR) & Balance (EUR) \\
\hline \multirow{2}{*}{4} & ort &, 162 & \multirow{2}{*}{\multicolumn{2}{|c|}{$\begin{array}{ll}5.156 & : 17 \\
\text { avorable } & \frac{11}{11}\end{array}$}} \\
\hline & ort & 16 & & \\
\hline \multirow{2}{*}{5} & ort & ,370 & \multirow{2}{*}{-.618 Unfavorabl $\frac{68}{81}$} & \multirow{2}{*}{587 Unfavorable } \\
\hline & ort & 152 & & \\
\hline \multirow{2}{*}{6} & ort &, 082 & \multirow{2}{*}{-584 Unfavorable $\frac{121}{360}$} & \multirow{2}{*}{061 Unfavorable } \\
\hline & ort & 198 & & \\
\hline \multirow{2}{*}{7} & ort & ,938 & \multirow{2}{*}{-5.801 Unfavorabl $\frac{175}{.79}$} & \multirow{2}{*}{996 Unfavorable } \\
\hline & ort & 337 & & \\
\hline \multirow{2}{*}{8} & ort & ,709 & \multirow{2}{*}{\multicolumn{2}{|c|}{$\lceil .557$ Unfavorabli, $\underset{, 22}{, 72}$}} \\
\hline & ort & 52 & & \\
\hline
\end{tabular}

Source: author's contribution after INTRACEN, 2018

Within the group of exporters, company Unilact is also worth to be mentioned, as it is exporting to the EU countries dairy products both under the brands Unilact and $\mathrm{De} \mathrm{La}$ Ferma. Some estimate shows that annual value of Romanian dairy market is estimated at over the one billion EUR (INTRACEN, 2018), but approximately $40 \%$ of that is covering the non-tax market.

\section{Materials and methods}

It was conducted the survey (based on opinion) on consumer's perception on dairy products safety. Used instrument for data collecting was questionnaire, which includes several sets of questions (demographic, related to frequency of consumption, or the type of consumed products, the quantity purchased at a single purchase, as well as regards the preferred brand of dairy products and the most important product's characteristics that affect purchasing decision). Questionnaire is revealing consumers' willing for safer products according to their quality and compliance with ISO 9001 standards.

The research objectives were to evaluate part of population which consumes milk and dairy products, to know consumers' preferences related to milk and dairy products, to track the frequency of consumption, to determine the main reasons that initiate the purchase of dairy products, to identify factors that affect purchasing and consumption, etc.

Research was based on next hypotheses:

$\checkmark$ The most of respondents are consuming the milk and dairy products;

$\checkmark$ The most of respondents consumes mentioned products weekly;

$\checkmark$ The most of consumers appreciate quality, then flavor, and just some of them the taste;

$\checkmark \quad$ Majority consumes the products they are used to consume, but some of them are tempted to try new products, even for once;

$\checkmark \quad$ Minority believes that widely promoted dairy products are safe. 
Paper importance is find in fact that the level of understanding consumers' motives when buying milk and dairy products greatly affects the producers, importers and retailers to timely and adequately organize all production/distribution activities and offer products in line to full consumers' satisfaction (Vlahović et al., 2012).

In order to verify mentioned assumptions, survey is conducted by the use of the interview (questionnaire) as a method of investigation. For the sampling method was used the method of quotas. Questionnaire contains twelve questions. It was distributed online or through the face-to-face interviews (interview lasted approximately 5 minutes).

Size of sample was 188 respondents, where 162 were women (around $86 \%$ of all respondents). The majority of respondents (161 persons, or $85.6 \%$ ) were at age group 15-35 years, 20 persons (10.6\%) were aged between $35-55$ years, while the rests $(3.7 \%)$ belong to the age group over 55 years. At the same time, 113 respondents $(60.1 \%)$ were students, 4 respondents $(2.1 \%)$ were unemployed, 32 respondents (17\%) were employees with high school degree, 38 respondents $(20.2 \%)$ were employees with higher education and one respondent $(0.5 \%)$ was retired. The respondents reported the following incomes: 67 persons $(35.6 \%)$ have monthly income below $700 \mathrm{RON}, 64$ persons (34\%) have monthly income in range from 700 RON to 1,500 RON, 57 persons (37.4\%) have monthly incomes exceeding 1,500 RON.

\section{Results and discussions}

If frequency of consumption is in focus, $43.8 \%$ of respondents consume milk and dairy products on daily basis, while $30.3 \%$ of them consume two to three times per week, or $18 \%$ consume once a week, $5.6 \%$ respondents consume two to three times per month and $2.2 \%$ of them consume milk and dairy products only once per month (Figure 6).

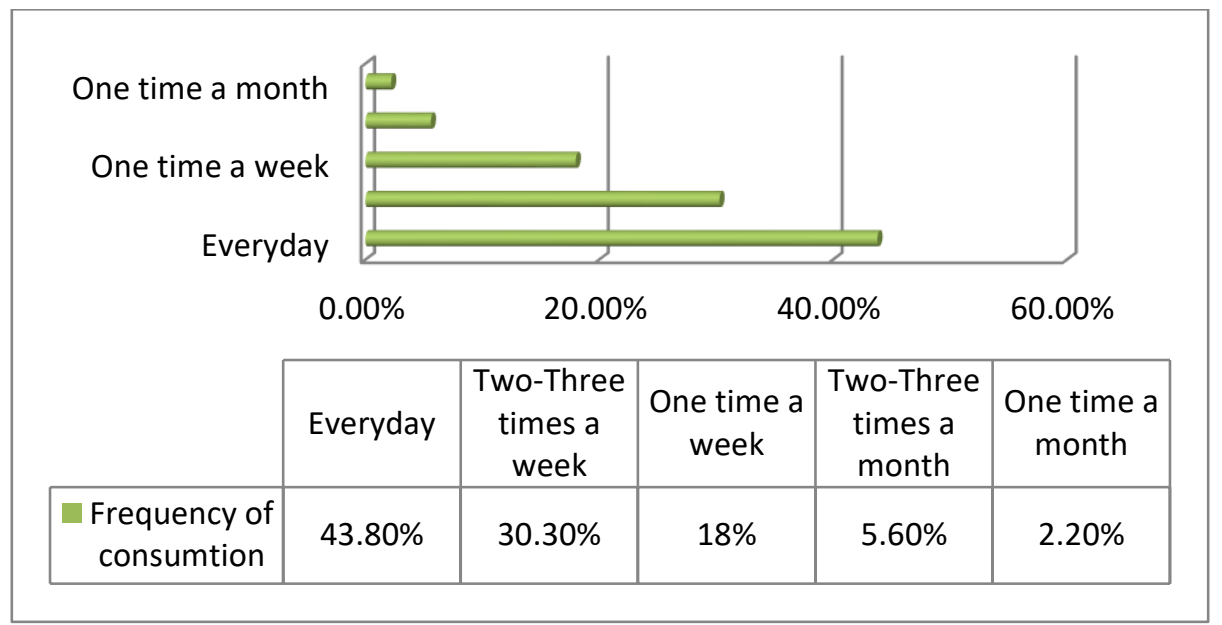

Figure 6. Frequency of milk and dairy products consumption Source: Results of the survey 
Next question was turned towards the consideration of consumed products safety. Respondents had to evaluate on the scale from 1 to 3 , how safe they are considering the dairy products they consume?

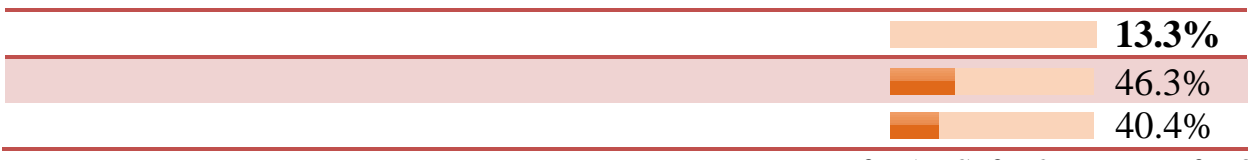

Figure 7. Dairy safety milk products

Unsafe [1]; Safe [2]; Very safe [3] Source: Results of the survey

According to the respondent's perception on consumed dairies' safety (Figure 7.), $46.3 \%$ of them believe that products they consume are safe, while $40.4 \%$ of respondents consider consumed products very safe. Only $13.3 \%$ of them think that used milk and dairy products are unsafe for human consumption.

Respondents are also asked to evaluate characteristics of the dairy products they consume (Figure 8.), ranking them according the strongest importance they have on decision making within the products purchasing.

It could be noticed that the majority of respondents $(82.4 \%)$ consider products safety as the most important factor that initiates the purchase.

Besides, quality is important for 154 respondents $(81.9 \%)$, while price impacts the purchase at 114 respondents $(60.6 \%)$.

The least important decision criterias related to purchase of milk and dairy products are product packaging and promotional activities.

Average marks recorded by each criterion are: safety and quality with 2.78 points, price with 2.04 points, packaging with 1.70 points and promotion with 1.63 points. Thus, the most desired aspect for consumers are products' quality and safety, while the price, packaging and promotion have smaller role within the decision making.

\begin{tabular}{cc} 
Price & \\
\hline & $\mathbf{1 7 . 6 \%}$ \\
\hline Quality & $60.6 \%$ \\
\hline & $21.8 \%$ \\
\hline & $\mathbf{3 . 2 \%}$ \\
\hline Safety & $14.9 \%$ \\
\hline & $81.9 \%$ \\
\hline & $\mathbf{4 . 3 \%}$ \\
\hline & $13.3 \%$ \\
\hline & $82.4 \%$ \\
\hline
\end{tabular}


Figure 8. Consideration of characteristics of milk and dairy products according to their importance during the purchase

\section{Conclusions}

Source: Results of the survey

Food quality is an important requirement in food production, as the consumers are sensitive to any form of contamination that may occur during the food preparation and distribution.

The paper presented an overview of the Romanian milk and dairy market, revealing that it is dynamic.

The current average monthly consumption of milk at national level is around 6 liters per capita, what justifies the importance of this product in human nutrition.

In the paper shown results reveal that food quality and safety are importants criterion used by consumers when they make decisions on the food they buy.

Gained results are useful for food processors and distributors towards the understanding consumer's purchasing perceptions and behavior related to milk and dairy products quality and safety. Furthermore, food processing companies could make adequate decisions on their food quality policy, or may implement into their core business food safety management system.

\section{References}

Arsić, S., Bulatović, M., Rakin, M., Jeločnik, M., Subić, J., 2018, "Economic and ecological profitability of the use of whey in dairy and food industry", Large Animal Review, vol. 24, no. 3, pp. 99-105.

Balambal, R. V., 2015, Ethical values of food safety, in: Food Security and Food Safety for the $21^{\text {st }}$ Century, proceedings of APSAFE 2013, Edt.: Hongladarom, S., Springer, Heidelberg, Germany, pp. 33-44. 
Banu, C., Barascu, E., Stoica, A., Nicolau, A., 2007, "Food sovereignty, security and safety", ASAB Publishing House, Bucharest, Romania.

Cao, R. Z., He, X. Y., Zhang, H., Wang, F. C., 2011, "Establish trust from whole chain traceability", Proceedings of 2011 IEEE International Conference on Service Operations, Logistics and Informatics, Beijing, China, pp. 325-330.

Handford, C. E., Campbell, K., Elliott, C. T., 2016, "Impacts of Milk Fraud on Food Safety and Nutrition with Special Emphasis on Developing Countries", Comprehensive Reviews in Food Science and Food Safety, vol. 15, no. 1, pp. 130-142.

Haug, A., Hostmark, A. T., Harstad, O. M., 2007, "Bovine milk in human nutrition: A review, Lipids in Health and Disease, vol. 6, no. 25, pp. 1-16.

Hemme, T., Otte, J., 2010, "Status of and Prospects for Smallholder Milk Production: A Global Perspective", FAO, Rome, Italy.

Jeločnik, M., Zubović, J., 2018, "Irrigation and Food Security: Case of Soybean Production in Serbia", in: Establishing Food Security and Alternatives to International Trade in Emerging Economies, Edt.: Erokhin, V., IGI Global, Hershey, USA, pp. 269-296.

Manole, V., Stoian, M., Ion, R. A., 2003, "Agromarketing", ASE Publishing House, Bucharest, Romania.

Sandu, M., 2015, "Traceability - Requirements to Ensure People's Food Security", Public Security Studies, vol. 4, no. 2(14), pp. 15-24.

Sharma, R., 2005, "Diet Management guide", Diamond Books, New Delhi, India.

Stetca, G., Nicolae, M., Pop, A., 2012, "Food Quality Management Strategies", Risoprint Publishing House, Cluj-Napoca, Romania.

Vlahović, B., Potrebić, V., Jeločnik, M., 2012, "Preferences of wine consumers on Serbian market", Economics of Agriculture, vol. 59, no. 1, pp. 37-49. 